\title{
KAJIAN PENGEMBANGAN SISTEM PENYEDIAAN AIR BERSIH PADA DAERAH RAWAN AIR DI DESA SUMBERSIH KECAMATAN PANGGUNGREJO KABUPATEN BLITAR
}

\author{
Elin Rohmaningsih ${ }^{1}$, Mohammad Sholichin ${ }^{2}$, Riyanto Haribowo ${ }^{2}$ \\ ${ }^{1}$ Staf Bidang Penyehatan Lingkungan, Dinas Perumahan dan Kawasan Permukiman Kabupaten Blitar \\ ${ }^{2}$ Dosen Jurusan Teknik Pengairan, Fakultas Teknik, Universitas Brawijaya, Malang \\ e-mail : elin.rohm4ningsih@gmail.com, mochsholichin@ub.ac.id, riyanto_haribowo@ub.ac.id
}

\begin{abstract}
ABSTRAK : Desa Sumbersih merupakan salah satu desa rawan air di Kabupaten Blitar. Di desa ini sebenarnya terdapat potensi air bersih yang sangat besar yaitu mata air Umbul Marijan. Namun sampai saat ini, pemanfaatannya masih sangat terbatas. Tujuan dari penelitian ini adalah mengkaji usaha pengembangan sistem penyediaan air bersih di Desa Sumbersih, pada aspek hidrolika, kualitas air, dan ekonomi. Analisa hidrolika dan kualitas air dilakukan memakai program WaterCAD V8i. Analisa ekonomi untuk menentukan harga air, dilakukan dengan skenario pengoperasian pompa menggunakan listrik dan solar cell. Hasil analisa hidrolika menunjukkan bahwa kondisi hidraulis jaringan perpipaan masih pada batas persyaratan teknis yang ditentukan, dengan kecepatan 0,03-0,97 m/dt, headloss gradient 0,09-14,45 m/km dan tekanan 11,18-69,31 $\mathrm{mH}_{2} \mathrm{O}$. Kemudian, model hidrolika tersebut digunakan untuk analisa sisa klorin. Penginjeksian klorin dilakukan pada tandon sebesar $0,4 \mathrm{mg} / \mathrm{l}$ secara konstan. Sisa klorin yang dihasilkan memenuhi persyaratan yaitu $0,34-0,39 \mathrm{mg} / \mathrm{l}$. Hasil analisa ekonomi menunjukkan bahwa skenario dengan solar cell memberikan harga air lebih rendah yaitu $\mathrm{Rp} 6.550,00 / \mathrm{m}^{3}$. Berdasarkan kemampuan membayar masyarakat Rp. $4.200,00 / \mathrm{m}^{3}$, dapat diketahui bahwa nilai subsidi pemerintah yang diperlukan sebesar Rp. 685.400.000,00.
\end{abstract}

Kata kunci : Air bersih, Jaringan perpipaan, WaterCAD V8i, Sisa Klorin, Harga air

\begin{abstract}
Sumbersih village is one of the water severe areas in Blitar district. Actually, it has high potentials of clean water which is on particular water source called Umbul Marijan. However, there is still very little water development of this water source. The objectives of this research were to study the clean water development system at Sumbersih village by considering the hydraulic, water quality, and economical aspects. The hydraulic and water quality analysis were done by using WaterCAD V8i software. The economic analysis to calculate water prices was done by using an electric and solar cell pump operation scenarios. The hydraulic analysis results showed that the hydraulic condition of pipe networks is still on the technical requirements limit as specified, velocity of 0,03-0,97 m/s, headloss gradient 0,09-14,45 m/km and pressures of 11,18$69,31 \mathrm{mH}_{2} \mathrm{O}$. Then, this hydraulics model was used to make the chlorine residual analysis. The injection of the reservoir is carried out of $0,4 \mathrm{mg} / \mathrm{l}$ constantly. The chlorine residual is still under the required limits of 0,34-0,39 $\mathrm{mg} / \mathrm{l}$. The economic analysis results showed that the solar cell scenarios give lower water prices of $R p 6.550,00 / \mathrm{m}^{3}$. Based on people's willingness to pay for clean water $R p .4 .200,00 / \mathrm{m}^{3}$, it is concluded that the required subsidies from the government is Rp. 685.400.000,00.
\end{abstract}

Keywords : Clean water, Pipe network, Water CAD V8i, Residual chlorine, Water prices

Desa Sumbersih Kecamatan Pang-gungrejo merupakan salah satu desa rawan air di Kabupaten Blitar yang menjadi prioritas utama dalam pengembangan sistem penyediaan air bersih. Jaringan perpipaan eksisting masih sangat terbatas. Terdapat 2 (dua) dusun yang belum terlayani perpipaan air bersih dengan baik yaitu Dusun Sumbersih dan Dusun Sumberpucung. Kedua dusun inilah yang akan menjadi sasaran pengembangan sistem jaringan perpipaan air bersih. Di Desa Sumbersih terdapat potensi air bersih 
yang cukup besar yaitu mata air Umbul Marijan. Tepatnya terletak di Dusun Sumberpucung. Namun sampai saat ini, pemanfaatannya masih sangat terbatas.

Dalam Rencana Pembangunan Jangka Menengah Nasional (RPJMN) ketiga tahun 2015-2019, terdapat output prioritas nasional di bidang Cipta Karya yaitu mewujudkan kawasan permukiman yang layak huni dan berkelanjutan, meliputi pelayanan air minum, penanganan kawasan kumuh, dan pelayanan sanitasi. Pemerintah menetapkan target dalam 5 (lima) tahun antara lain $100 \%$ capaian pelayanan akses air minum, 0\% proporsi rumah tidak layak huni di kawasan perkotaan, dan $100 \%$ capaian pelayanan akses sanitasi. Target tersebut dikenal dengan sebutan Key Performance Indicators 100-0-100.

Terkait dengan program tersebut, pada tahun 2014, Dinas PU Cipta Karya dan Tata Ruang Propinsi Jawa Timur telah melakukan penyusunan perencanaan sistem penyediaan air bersih di Desa Sumbersih. Kemudian pada tahun 2016, Dinas PU Cipta Karya dan Tata Ruang Kabupaten Blitar, sebagai pihak yang akan melaksanakan pembangunan fisik, melakukan review perencanaan dengan melakukan perubahan-perubahan.

Namun kajian teknis belum dilakukan. Oleh karena itu, kajian ini perlu dilakukan untuk menganalisa pengembangan sistem penyediaan air bersih di Desa Sumbersih.

Dalam sistem penyediaan air bersih, selain dari segi kuantitas dan kontinuitas, kualitas air bersih juga merupakan faktor penting yang perlu diperhatikan. Meskipun air tanah biasanya tidak terkontaminasi oleh bakteri, air tanah umumnya tetap memerlukan perlakuan desinfeksi dengan klorin guna menjamin air tersebut bebas dari kontaminasi bakteri (Suprihatin, et.al., 2013). Selain itu dalam sistem distribusi air, sangat memungkinkan terjadinya perubahan kualitas air. Listiyaningrum, et. al. (2015), dalam penelitiannya menyebutkan bahwa semakin lama umur air pada pipa distribusi menyebabkan semakin rendahnya kadar klorin. Semakin jauh jarak dari reservoir, maka kadar klorin akan semakin rendah pula.

Laju kehilangan klorin tersebut dipengaruhi oleh bulk reaction rate dan pipe wall reaction. Triatmadja, et. al. (2006), menyebutkan bahwa koefisien bulk hasil pelitian di laboratorium adalah $0,0 /$ hari, hal ini disebabkan oleh air yang digunakan relatif bersih dan bebas dari pencemaran. Namun mengingat umumnya keadaan air baku di Indonesia mengandung banyak bakteri dan mineral yang berpengaruh terhadap kualitas air, digunakan batas bawah seperti yang disebutkan Rossman (2000) yaitu $-0,001 \% / \mathrm{dt}$ $(-0,864 /$ hari). Sedangkan nilai pipe wall reaction bergantung pada jenis material pipa dan kondisinya. Rossman (2000) mem-berikan kisaran nilai pipe wall reactions untuk first order reaction yaitu $0-5 \mathrm{ft} / \mathrm{hari} \quad(0-1,524$ $\mathrm{m} /$ hari) tetapi dapat juga diabaikan (pipa beton atau pipa plastik) atau bisa jadi sangat tinggi (pipa dengan material yang mudah terkorosi). Triatmadja, et.al. (2006) memberikan nilai pipe wall reaction sebesar $-0,187 \mathrm{~m} /$ hari untuk pipa GI.

Lampiran III Permen PUPR Nomor : 27/PRT/M/2016, menyebutkan bahwa besarnya dosis klorin tergantung dari kualitas air bersih yang diproduksi serta ditentukan sisa klorin di instalasi adalah 0,3-0,5 mg/l. Dengan adanya penurunan sisa klorin, maka diperlukan pemodelan penginjeksian klorin untuk mengetahui berapa kadar klorin yang diperlukan agar konsentrasi sisa klorin memenuhi persyaratan yang telah ditentukan.

Tujuan dari studi ini adalah mengkaji pengembangan sistem penyediaan air bersih di Desa Sumbersih, pada aspek hidrolika, kualitas air, dan ekonomi. Analisa hidrolika dan kualitas air diperlukan untuk mengetahui jumlah kebutuhan air serta sistem penyediaan air bersih secara detail. Sedangkan analisa ekonomi diperlukan dalam memberikan alternatif untuk penetapan harga air.

\section{BAHAN DAN METODE}

\section{Lokasi Studi}

Lokasi studi terletak di Desa Sumbersih Kecamatan Panggungrejo Kabupaten Blitar (Gambar 1). Desa ini mempunyai luas wilayah $7,57 \mathrm{~km}^{2}$. Pada tahun 2016, jumlah penduduknya mencapai 3.069 jiwa. Topografi daerah ini merupakan kawasan perbukitan dan lembah, permukiman penduduk sebagian besar berada pada punggung bukit. 


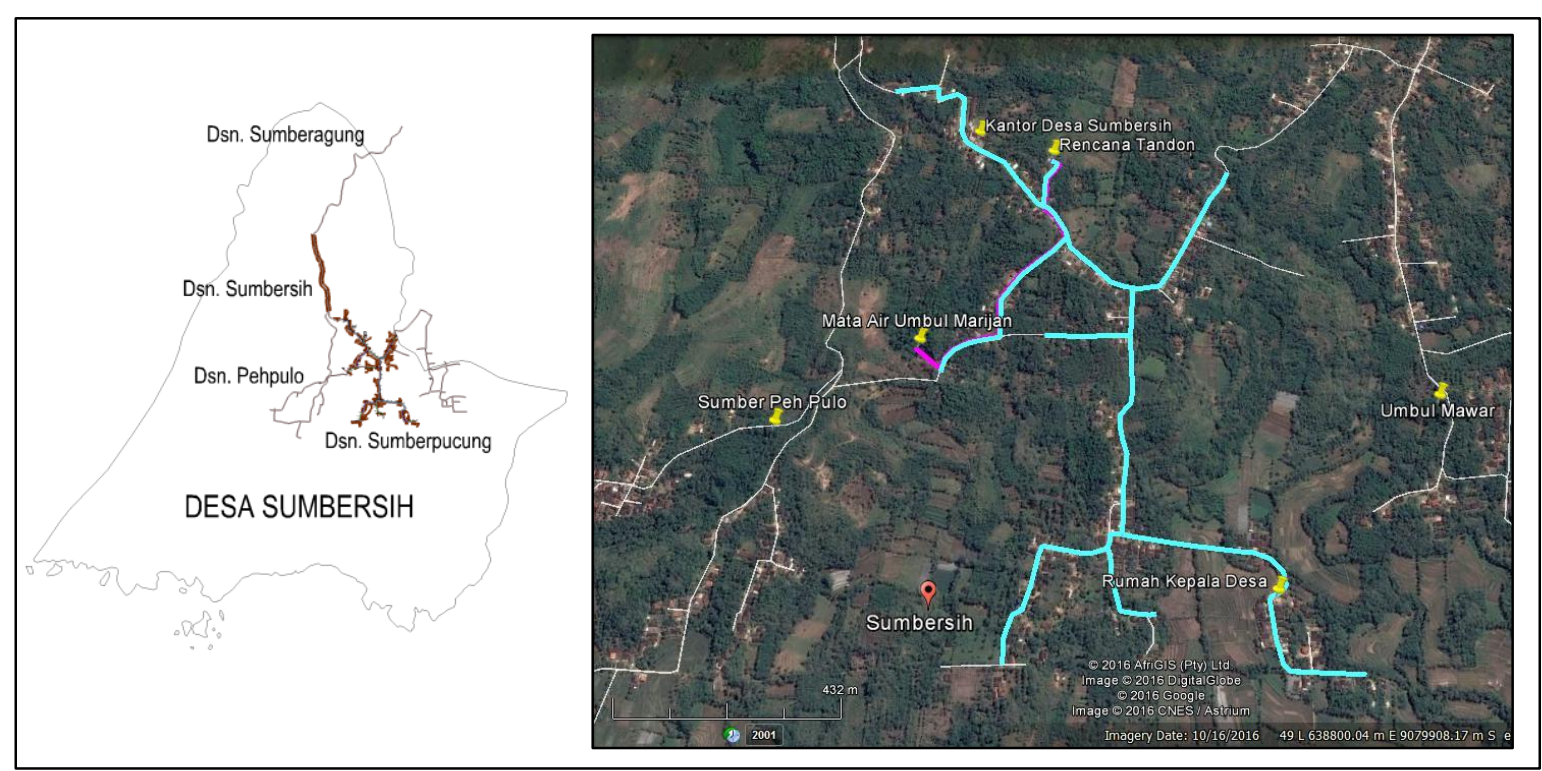

Gambar 1. Peta Lokasi Studi

Sumber : Dinas PU Cipta Karya dan Tata Ruang Prop. Jatim (2014) dan Google Earth (2016)

Tabel 1. Faktor Pengali (Load factor) terhadap kebutuhan harian

\begin{tabular}{lllllllllllll}
\hline Jam & $\mathbf{1}$ & $\mathbf{2}$ & $\mathbf{3}$ & $\mathbf{4}$ & $\mathbf{5}$ & $\mathbf{6}$ & $\mathbf{7}$ & $\mathbf{8}$ & $\mathbf{9}$ & $\mathbf{1 0}$ & $\mathbf{1 1}$ & $\mathbf{1 2}$ \\
\hline LF & 0,31 & 0,37 & 0,45 & 0,64 & 1,15 & 1,4 & 1,53 & 1,56 & 1,42 & 1,38 & 1,27 & 1,2 \\
\hline Jam & $\mathbf{1 3}$ & $\mathbf{1 4}$ & $\mathbf{1 5}$ & $\mathbf{1 6}$ & $\mathbf{1 7}$ & $\mathbf{1 8}$ & $\mathbf{1 9}$ & $\mathbf{2 0}$ & $\mathbf{2 1}$ & $\mathbf{2 2}$ & $\mathbf{2 3}$ & $\mathbf{2 4}$ \\
\hline LF & 1,14 & 1,17 & 1,18 & 1,22 & 1,31 & 1,38 & 1,25 & 0,98 & 0,62 & 0,45 & 0,37 & 0,25 \\
\hline
\end{tabular}

Sumber: DPU Ditjen Cipta Karya Direktorat Air Bersih (1994) dalam Lufira, R.D. (2012)

Tabel 2. Kriteria Jaringan Pipa

\begin{tabular}{lll}
\hline Keterangan & Pipa PVC & Pipa GI \\
\hline Kecepatan & $0,3-3,0 \mathrm{~m} / \mathrm{dt}$ & $0,3-6,0 \mathrm{~m} / \mathrm{dt}$ \\
Headloss Gradient & $0-15 \mathrm{~m} / \mathrm{km}$ & $0-15 \mathrm{~m} / \mathrm{km}$ \\
Tekanan & $\mathrm{Min} 10 \mathrm{mH}_{2} \mathrm{O}$ (SR terjauh) & Min $10 \mathrm{mH}_{2} \mathrm{O}$ (SR terjauh) \\
& Maks $80 \mathrm{mH}_{2} \mathrm{O}$ & Maks $100 \mathrm{mH}_{2} \mathrm{O}$ \\
\hline
\end{tabular}

Sumber : Lampiran III Permen PUPR (2016)

Mata air Umbul Marijan terletak di Dusun Sumberpucung, dengan elevasi 119,08 mdpl, lebih rendah dari daerah layanan. Dari mata air ini, direncanakan air akan dipompa menuju tandon yang ditempatkan pada lokasi dengan elevasi paling tinggi sehingga pendistribusian air ke daerah layanan, dapat dilakukan secara gravitasi.

\section{Pengumpulan Data}

Tahap pengumpulan data pada studi ini, meliputi pengumpulan data primer dan data sekunder. Data primer yang digunakan, antara lain:

1. Data debit mata air Umbul Marijan.

2. Data jumlah rumah dan sebaran rumah yang diperoleh melalui pengamatan lapangan dengan menggunakan bantuan Google earth.
3. Data kualitas air Umbul Marijan dengan pengambilan sampel air dan pengujian pada laboratorium kualitas air Perum Jasa Tirta I.

4. Data kemampuan membayar warga melalui pembagian kuisioner.

Sedangkan data sekunder yang digunakan, antara lain:

1. Data jumlah penduduk tahun 2011-2016.

2. Peta rencana jaringan pipa dan data topografi.

3. Daftar harga satuan upah dan bahan tahun 2016.

\section{Pengolahan Data} berikut:

Tahap pengolahan data adalah sebagai

1. Menghitung proyeksi jumlah penduduk. Proyeksi tersebut dapat dihitung dengan 
metode Geometrik, metode Aritmatik, serta metode Eksponensial (Muliakusumah, 1981). Menurut Permen PUPR Nomor : 27/PRT/M/2016 tentang Penyelenggaraan Sistem Penyediaan Air Minum, rencana induk SPAM disusun untuk jangka waktu 15-20 tahun. Sehingga pada studi ini, proyeksi penduduk dilakukan hingga 15 tahun kedepan mulai dari tahun 2016-2031.

2. Uji kesesuain metode proyeksi pendu-duk dengan membandingkan nilai koefi-sien korelasi.

3. Menghitung besarnya kebutuhan air bersih. Parameter yang ditetapkan, antara lain:

- Kebutuhan air bersih sebesar 60 1/ orang/hari, sesuai dengan Lampi-ran I Permen PUPR Nomor: 27/ PRT/M/2016.

- Kebutuhan non domestik sebesar $15 \%$ dari kebutuhan domestik (Triatmadja, 2016).

- Kehilangan air sebesar 20\% (Triatmadja, 2016).

- Fluktuasi kebutuhan air bersih ditetapkan berdasarkan Departemen Pekerjaan Umum Ditjen Cipta Karya Direktorat Air Bersih pada Tabel 1.

4. Analisa kebutuhan dan ketersediaan air bersih. Metode yang digunakan yaitu perbandingan antara debit kebutuhan air bersih rata-rata penduduk hasil perhitungan dengan data ketersediaan debit mata air hasil pengukuran dengan current meter sehingga dapat diketahui apakah debit mata air tersebut mampu memenuhi kebutuhan air bersih penduduk sampai dengan tahun 2031 .

5. Pembagian kebutuhan air pada masingmasing titik simpul (junction), dengan langkah-langkah sebagai berikut:

- Penentuan jumlah rumah eksisting yang dilayani oleh masing-masing junction dengan menggunakan fasilitas Thiessen Polygons pada Water CAD V8i.

- Dihitung prosentase layanan berdasarkan jumlah rumah eksisting yang dilayani pada masing-masing junction.

- Kemudian prosentase layanan pada masing-masing junction tersebut dikalikan dengan kebutuhan air hasil proyeksi, untuk mendapatkan kebu- tuhan air pada masing-masing titik simpul (junction).

6. Perencanaan tandon, dan pompa.

7. Analisa sistem jaringan perpipaan air bersih dengan menggunakan Program WaterCAD V8i, meliputi analisa hidrolika, kualitas air, analisa biaya pekerjaan pemasangan pipa dan analisa biaya lis-trik untuk operasi pompa. Kriteria jari-ngan pipa menurut Permen PUPR No :27/PRT/M/2016 seperti pada Tabel 2.

8. Menghitung konstruksi tandon menggunakan program StaadPro v8i.

9. Analisa biaya proyek. Pada studi ini, analisa biaya dilakukan dengan 2 (dua) skenario, yaitu:

- Skenario 1 : operasional pompa dengan listrik

- Skenario 2 : operasional pompa dengan solar cell

10. Analisa kelayakan ekonomi, meliputi:

- Benefit Cost Ratio (BCR)

Rumus perhitungan BCR yaitu (Giatman, 2007):

$\mathrm{BCR}=\frac{\text { PV Manfaat }}{\text { PV Biaya }}$

dengan:

$\mathrm{PV}=$ Present Value

$\mathrm{BCR}=$ Benefit Cost Ratio

- Net Benefit (B-C) yaitu selisih antara jumlah benefit dengan jumlah cost.

- Internal Rate of Return (IRR) Rumus perhitungan nilai IRR sebagai berikut (Kuiper, 1971):

$I R R=I^{\prime}+\frac{(B-C)^{\prime}}{(B-C)^{\prime}-(B-C)^{\prime \prime}}\left(I^{\prime \prime}-I^{\prime}\right)$

dengan:

I' = suku bunga memberikan nilai (B-C) positif

I" = suku bunga memberikan nilai (B-C) negatif

$(\mathrm{B}-\mathrm{C})^{\prime}=$ Net benefit $(\mathrm{B}-\mathrm{C})$ positif

$(\mathrm{B}-\mathrm{C}) "=$ Net benefit $(\mathrm{B}-\mathrm{C})$ negatif

- Titik impas investasi (payback periode), dapat dihitung dengan rumus (Giatman, 2007):

$\mathrm{k}=\frac{\text { investasi }}{\text { annual benefit }} \times$ periode waktu 
dengan:

\begin{tabular}{|c|c|}
\hline $\mathrm{k}$ & $=\begin{array}{l}\text { periode pengem- } \\
\text { balian }\end{array}$ \\
\hline Investasi & $\begin{array}{l}=\text { modal yang diper- } \\
\text { lukan }\end{array}$ \\
\hline Annual benefit & 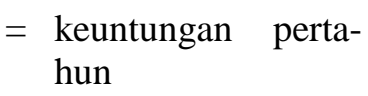 \\
\hline
\end{tabular}

- Analisa sensitivitas

Beberapa keadaan digunakan untuk analisa sensitivitas, antara lain:

a) Terjadi $10 \%$ penurunan nilai manfaat/benefit.

b) Terjadi $10 \%$ kenaikan biaya/cost yang diperlukan.

c) Tertundanya waktu selesai proyek selama 2 (dua) tahun.

11. Penetapan harga air per $\mathrm{m}^{3}$.

\section{HASIL DAN PEMBAHASAN Proyeksi Jumlah Penduduk}

Berdasarkan proyeksi jumlah penduduk pada daerah layanan sampai tahun 2031, diperoleh hasil sebesar 3.002 jiwa. Jumlah ini yang nantinya akan digunakan sebagai dasar perhitungan proyeksi kebutuhan air bersih.

\section{Analisa Kebutuhan dan Ketersediaan Air Bersih}

Jumlah kebutuhan air bersih di Desa Sumbersih untuk keseluruhan daerah layanan yaitu Dusun Sumbersih dan Dusun Sumberpucung, sampai tahun 2031 seba-gai berikut:

- Kebutuhan air bersih rata-rata sebesar $2,88 \mathrm{l} / \mathrm{dt}$

- Kebutuhan air bersih harian maksimum sebesar 3,31 1/dt

- Kebutuhan air bersih pada jam pun-cak sebesar 4,49 1/dt

Ketersediaan debit mata air Umbul Marijan berdasarkan hasil pengukuran dengan current meter sebesar 289,48 1/dt, dan debit kebutuhan rata-rata penduduk sebesar 2,88 1/dt, mampu melayani $100 \%$ kebutuhan penduduk dengan kehilangan air $20 \%$. Dengan kebutuhan rata-rata sebesar $2,88 \mathrm{l} / \mathrm{dt}$, masih terdapat sisa debit 286,60 1/dt. Sehingga debit mata air Umbul Marijan yang tersedia mampu mencukupi kebutuhan air bersih penduduk Desa Sumbersih sampai dengan tahun 2031 dan masih terdapat sisa debit.

\section{Simulasi Program WaterCAD V8i \\ Simulasi Hidrolika}

Pemodelan program WaterCAD V8i

menggunakan beberapa asumsi, yaitu:

1. Reservoir merupakan bangunan penang-kap mata air Umbul Marijan.

2. Untuk mengatur agar pompa bekerja pada head yang tetap (inflow konstan) maka digunakan flow control valve (FCV) setelah pompa. FCV ini hanya digunakan sebagai alat bantu karena program WaterCAD V8i menghitung head statis dari sistem $\left(\mathrm{z}_{\mathrm{B}}\right)$ berdasarkan fluktuasi muka air tandon.

Digunakan pompa Grundfos CR 1508 dan tandon dengan kapasitas $64 \mathrm{~m}^{3}$. Daerah studi merupakan daerah dengan keadaan topografi yang naik turun/berbukit, sehingga agar dapat mendistribusikan air bersih secara gravitasi ke seluruh daerah layanan, dibuat elevated reservoir (tandon menara) dengan peninggian 3 (tiga) meter.

Pipa yang digunakan adalah pipa Pipa Swallow Standard SNI 06-0084-2002 (PVC S10) dan Pipa Galvanized iron me-dium SNI. Diameter pipa yang digunakan be-ragam (Gambar 2). Simulasi dengan program WaterCAD V8i dilakukan dengan periode waktu tertentu (Extended Period Simulation) yaitu 72 jam atau 3 hari, untuk memperkirakan kapasitas optimal tandon.

Simulasi diawali dengan elevasi muka air tandon $3 \mathrm{~m}$. Operasi pompa 14 jam perhari dengan debit inflow 5,25 1/dt (pompa menyala tiap 5 jam, istirahat pompa 2 jam), pompa mulai beroperasi pukul 05.00 . Untuk menghindari adanya volume air yang terbuang tersebut, maka pompa pada jam terakhir dioperasikan selama 10 menit saja. Pompa dimatikan pada pukul 22.10. Pada jam ke 24.00 tandon berada pada tinggi muka air yang hampir sama dengan awal pengoperasian sehingga pola pengoperasian dapat konstan pada hari berikutnya (Gambar 3).

Kecepatan yang terjadi di jaringan pipa transmisi pada jam puncak, berkisar antara 0,41 m/dt sampai 0,65 m/dt. Kecepa-tan paling tinggi terdapat pada pipa 18 , sedangkan kecepatan paling rendah pada pipa 71 dan 72 (Gambar 4). Pada jam rendah di mana kebutuhan menjadi kecil maka kece-patan aliran pun menjadi kecil yaitu berkisar antara $0,03 \mathrm{~m} / \mathrm{dt}$ sampai $0,18 \mathrm{~m} / \mathrm{dt}$. 


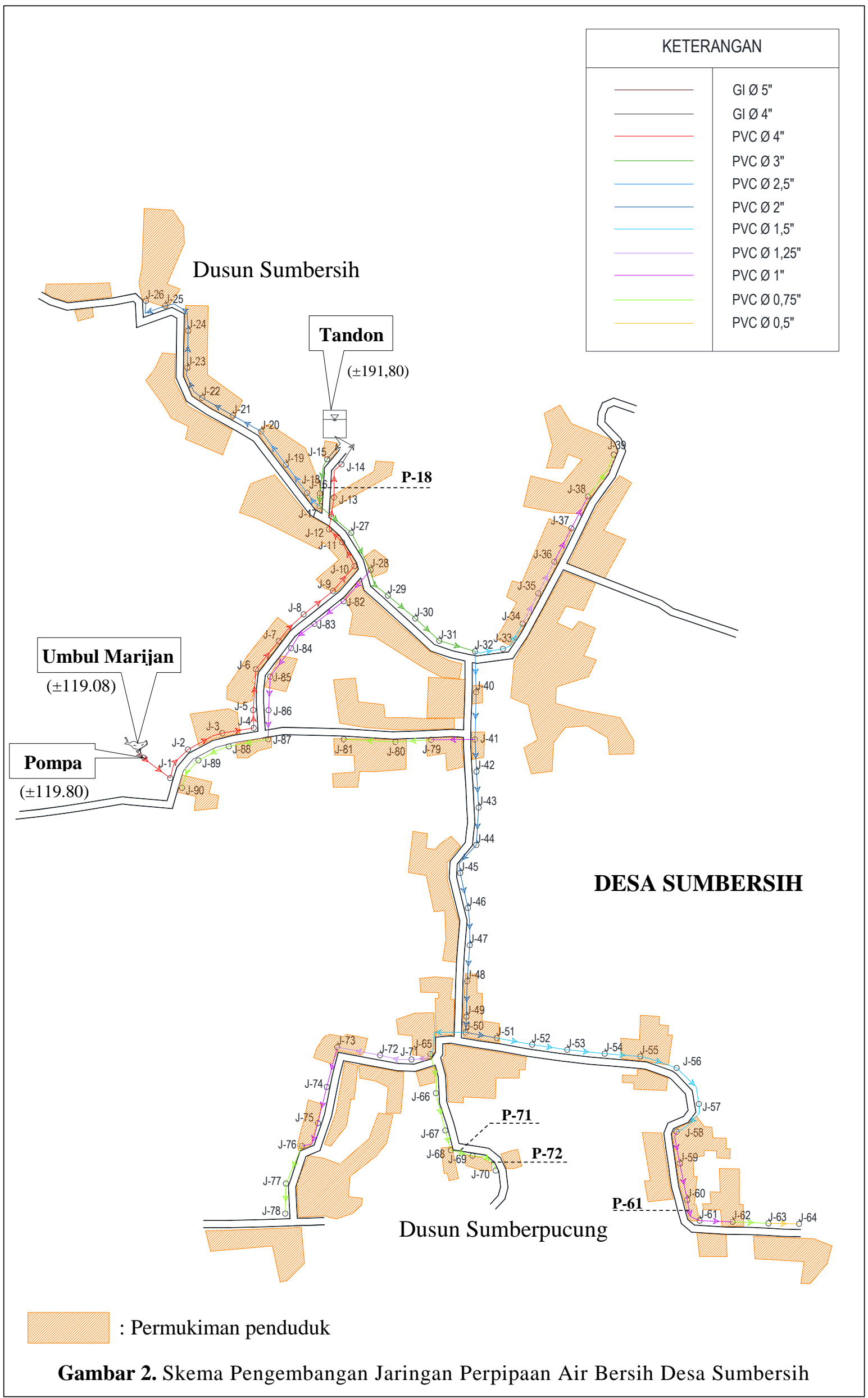




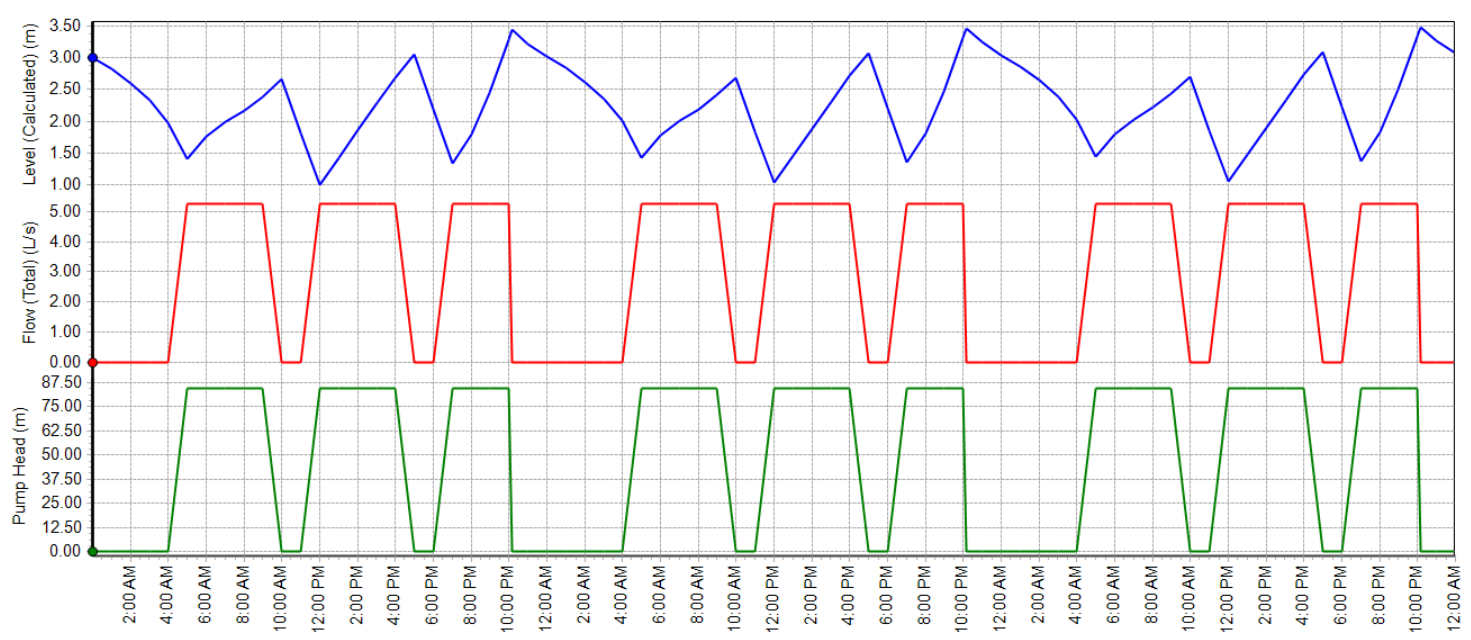

Time

- T-1 Level (Calculated) - PMP-1 Flow (Total) $\quad$ - PMP-1 Pump Head

Gambar 3. Grafik Debit Pompa, Head Pompa, dan Fluktuasi Muka Air Tandon

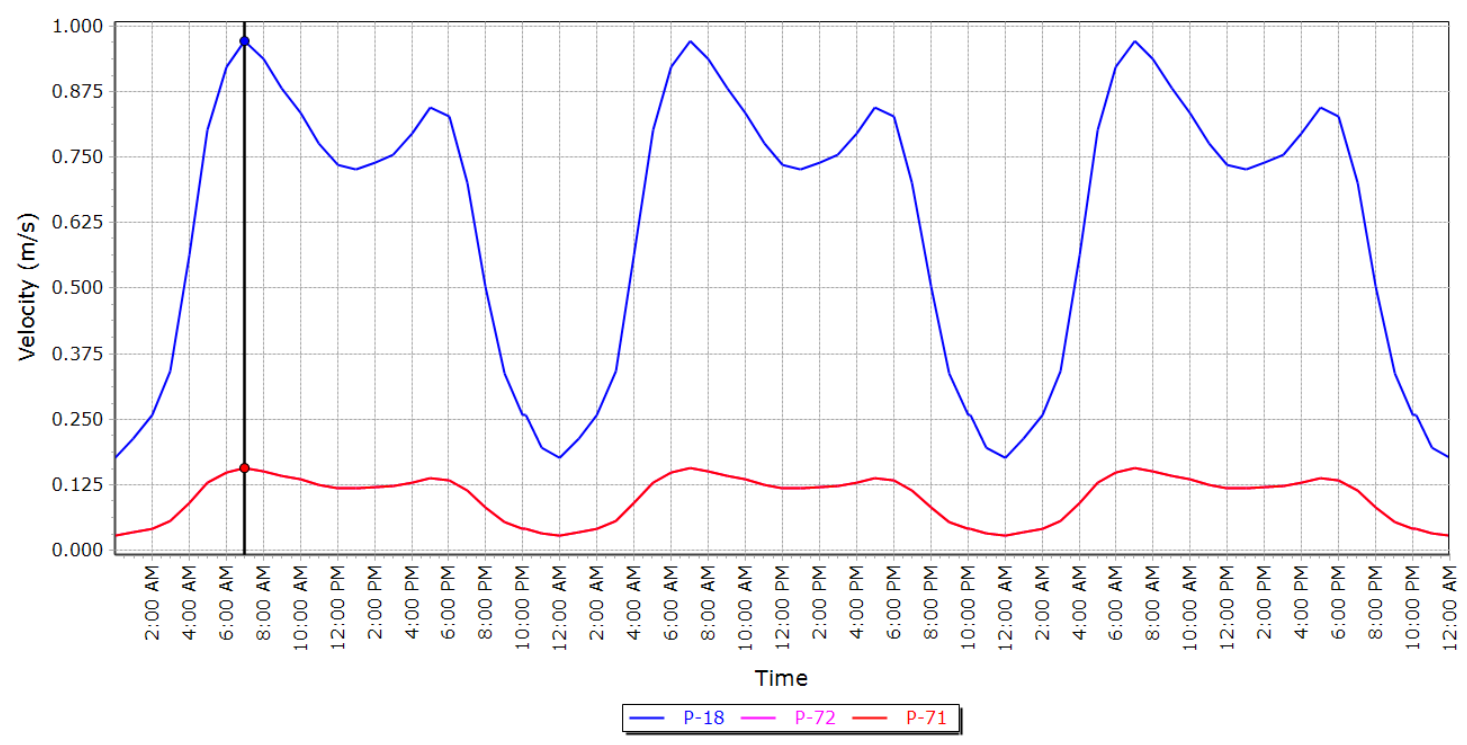

Gambar 4. Grafik Fluktuasi Kecepatan Pipa 18, Pipa 71 dan Pipa 72

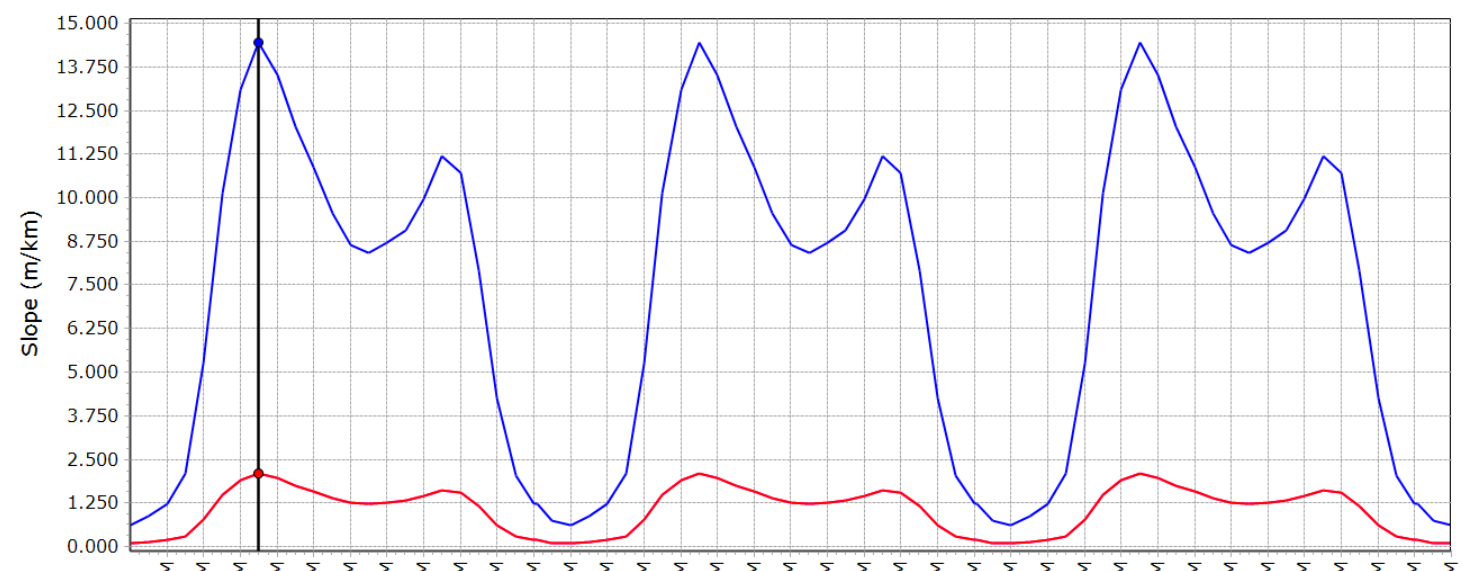

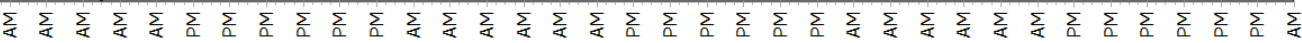

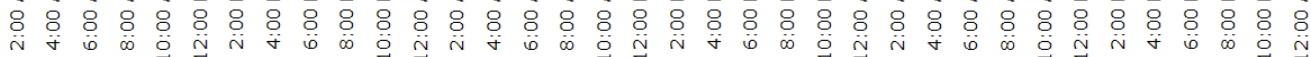

$$
\begin{gathered}
\text { Time } \\
\square \mathrm{P}-72-\mathrm{P}-71-\mathrm{P}-61
\end{gathered}
$$

Gambar 5. Grafik Fluktuasi Headloss Gradient Pipa 61, Pipa 71, Pipa 72 


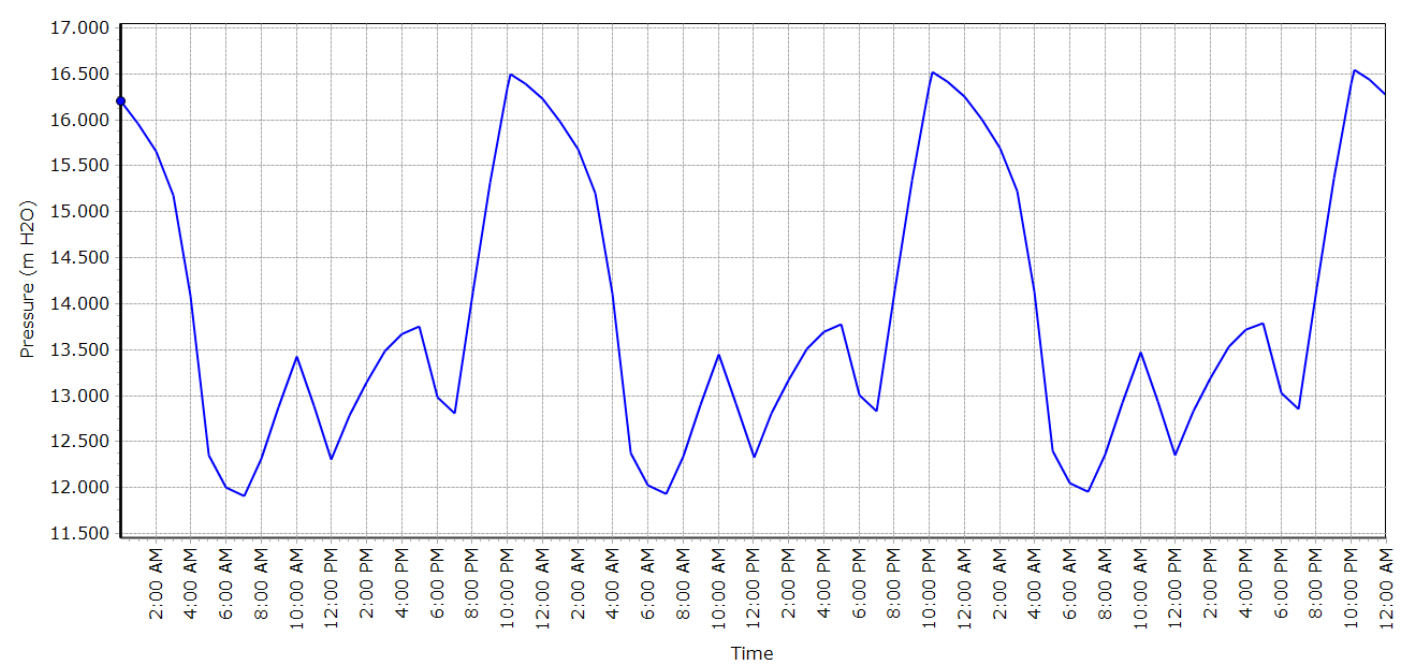

Gambar 6. Grafik Fluktuasi Tekanan di Titik J-26

Sedangkan Headloss gradient pada jam puncak besar berkisar antara 2,09 m/km sampai 14,45 m/km. Headloss gradient terbesar pada jam puncak terdapat pada pipa 61 dan terkecil pada pipa 71 dan 72 (Gambar 5). Sedangkan pada jam rendah berkisar antara $0,09 \mathrm{~m} / \mathrm{km}$ sampai $0,61 \mathrm{~m} / \mathrm{km}$.

Secara umum headloss gradient dan kecepatan pada jaringan pipa telah sesuai dengan kriteria perencanaan, walaupun pada beberapa titik masih terdapat kecepatan yang masih kurang dari $0,3 \mathrm{~m} / \mathrm{dt}$. Solusi penggantian pipa dengan diameter yang lebih ke-cil hanya akan memperbesar headloss gra-dient, oleh sebab itu tidak dapat dilakukan. Untuk itu perlu dilakukan pengurasan pipa secara berkala guna mencegah terjadinya sedimentasi. Kecepatan terlalu rendah terjadi pada pipa-pipa dead end, sehingga akan dipasang katub penguras (blow off/BO) sebanyak 7 buah pada setiap dead end.

Pada jalur pipa transmisi, tekanan sisa pada tiap titik simpul pada jam puncak berkisar $\begin{array}{llll}\text { antara } & 11,72 \quad \mathrm{mH}_{2} \mathrm{O} & \text { hingga } & 61,79\end{array}$ $\mathrm{mH}_{2} \mathrm{O}$.Sedangkan pada jam rendah, tekanan berkisar antara 12,42 $\mathrm{mH}_{2} \mathrm{O}$ hingga 60,2 $\mathrm{mH}_{2} \mathrm{O}$. Sedangkan pada jalur pipa distribusi, pada jam puncak berkisar antara $11,18 \mathrm{mH}_{2} \mathrm{O}$ hingga $57,75 \mathrm{mH}_{2} \mathrm{O}$. Pada jam rendah berkisar antara $12,41 \mathrm{mH}_{2} \mathrm{O}$ hingga $69,31 \mathrm{mH}_{2} \mathrm{O}$.

J-26 yang merupakan salah satu titik simpul terjauh, pada jam rendah tekanannya mencapai 16,20 $\mathrm{mH}_{2} \mathrm{O}$ sedangkan pada jam puncak tekanannya turun menjadi $11,91 \mathrm{mH}_{2} \mathrm{O}$ (Gambar 6). Tekanan maksimum terjadi pada saat pukul 22.10 sebesar $16,50 \mathrm{mH} 2 \mathrm{O}$ karena pada pukul 22.10 tandon pada posisi penuh ( $\mathrm{h}_{\text {air }}$ tandon lebih besar dari $\mathrm{h}_{\text {initial }}$ ), sehingga hydraulic gradenya paling besar. Dengan kondisi tersebut, maka seluruh jaringan perpipaan telah memenuhi kriteria persyaratan tekanan dan kebutuhan air bersih di tiap titik simpul dapat terpenuhi.

\section{Simulasi Sisa Klorin}

Klorin sebagai desinfektan diperlukan untuk memastikan air minum yang didistribusikan tetap higienis. Dalam pemodelan konsentrasi klorin menggunakan program WaterCAD V8i diperlukan input data sebagai berikut:

1. Koefisien difusi (diffusivity) $=1,208 \times 10^{-9}$ $\mathrm{m}^{2} / \mathrm{s}$ (nilai default pada WaterCAD V8i). Jenis klorin yang akan digunakan adalah klorin cair atau Sodium Hypochlorite ( $\mathrm{NaOCl})$.

2. Bulk reaction rate $=-0,864 /$ hari. Berdasarkan hasil uji laboratorium menurut Permenkes RI Nomor:492/MENKES /PER/IX/2010, kualitas air Umbul Marijan memenuhi syarat kriteria air bersih, sehingga dalam pemodelan digunakan nilai bulk reaction rate $-0,864 /$ hari.

3. Reaksi dengan dinding pipa (wall reaction), $\mathrm{k}_{\mathrm{w}}=0 \mathrm{~m} / \mathrm{hari}$ (pipa $\mathrm{PVC}$ ) dan $\mathrm{k}_{\mathrm{w}}=-0,187 \mathrm{~m} / \mathrm{hari}$ (pipa GI). Pada studi ini, pipa yang dianalisa merupakan jaringan pipa baru yang sebagian besar memakai pipa PVC, kondisinya diang-gap $100 \%$ baik sehingga pipe wall reaction diabaikan (sama dengan nol). Sedangkan pada pipa GI, pipe wall reaction digunakan $-0,187 \mathrm{~m} /$ hari (Triat-madja, et. al., 2006).

Injeksi klorin dilakukan pada pipa inlet tandon. Klorin membutuhkan waktu untuk 
bercampur dengan air. Selain itu klorin membutuhkan waktu untuk mematikan bakteri penyakit. Dengan menginjeksi klorin pada inlet tandon akan mempermudah pencampuran klorin secara merata. Selain itu, ada jeda waktu atau dwelling time sebelum air keluar melalui outlet, klorin akan bekerja mematikan bakteri patogen dalam air tandon selama waktu tunggu tersebut. Dengan demikian diharapkan saat air keluar melalui outlet, masuk ke jaringan distribusi sudah bebas dari bakteri patogen.

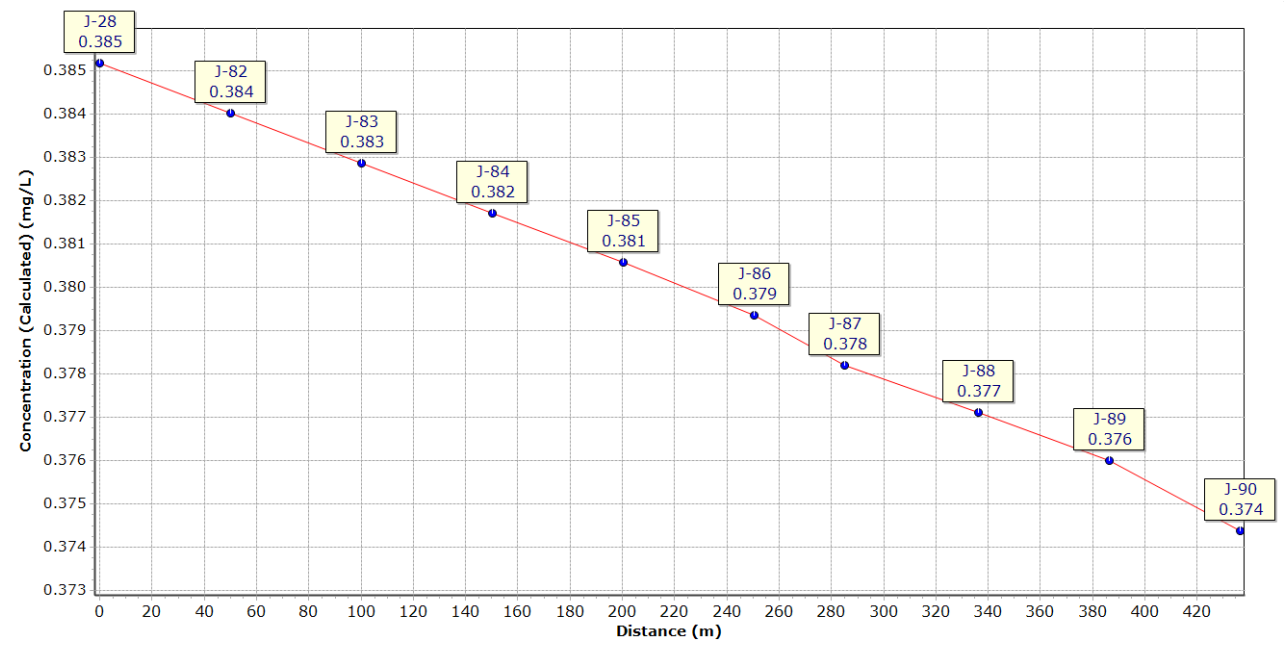

Gambar 7. Konsentrasi Sisa Klorin pada Junction (Pukul 07.00 hari kedua)

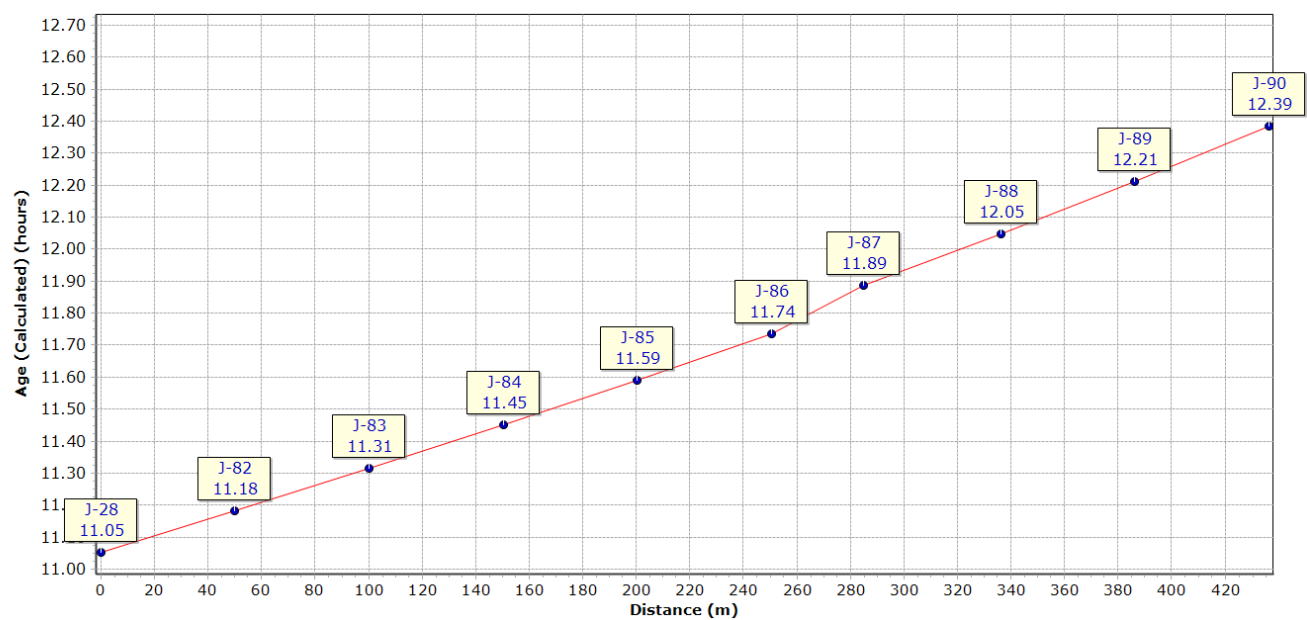

Gambar 8. Waktu Tinggal Air pada Pipa (Pukul 07.00 hari kedua)

Pada simulasi penginjeksian klorin, digunakan dosis klorin pada tandon sebesar 0,4 $\mathrm{mg} / \mathrm{l}$ secara konstan. Hasilnya, pada pukul 04.00 telah terdapat sisa klorin di seluruh junction, namun masih ada beberapa junction yangbelum memenuhi kriteria persyaratan. Pada pukul 05.00, sisa klorin pada seluruh junction jaringan perpipaan berada pada kisaran 0,35-0,39 mg/l, sehingga pada pukul 05.00 air mulai aman untuk digunakan oleh pelanggan. Penginjeksian $0,4 \mathrm{mg} / \mathrm{l}$ secara konstan ini menghasilkan sisa klorin pada jam puncak $0,35-0,39 \mathrm{mg} / \mathrm{l}$, sedangkan pada jam rendah $0,34-0,39 \mathrm{mg} / \mathrm{l}$, sehingga memenuhi syarat kriteria sisa klorin yaitu 0,3-0,5 mg/l. Konsentrasi sisa klorin akan semakin berkurang dengan semakin bertambahnya jarak junction dari tandon (Gambar 7). Pada J-28 konsentrasi sisa klorin $0,38 \mathrm{mg} / \mathrm{l}$, pada $\mathrm{J}-82$ turun menjadi $0,38 \mathrm{mg} / \mathrm{l}$, sedangkan pada titik terjauh J-90, konsentrasi sisa klorin semakin menurun menjadi $0,36 \mathrm{mg} / \mathrm{L}$. Sedangkan waktu tinggal air pada jam puncak dihari kedua (Gambar 8), pada J-28 selama 11,05 jam, pada J-82 meningkat menjadi 11,18 jam. Waktu tinggal terlama pada J-90 yaitu 12,39 jam. Waktu tinggal air sangat dipengaruhi oleh debit kebutuhan air pada junction tersebut dan kecepatan aliran dalam pipa. 


\section{Analisa Biaya Pekerjaan dengan Program WaterCAD V8i}

Program WaterCAD V8i memberikan fasilitas untuk menghitung estimasi biaya konstruksi jaringan pipa dengan memakai tools Darwin Designer. Didapatkan total kebutuhan biaya pekerjaan pengadaan dan pemasangan pipa, berdasarkan hasil analisa dengan Darwin Designer yaitu sebesar Rp. 294.467.849,00.

Selain itu, Program WaterCAD V8i juga memberikan fasilitas untuk menghitung biaya listrik yang dibutuhkan untuk kerja pompa dengan memakai tools Scenario Ener-gy Cost. Biaya listrik yang harus dikeluarkan sebesar Rp. 4.318.860,00/bulan.

\section{Analisa Konstruksi Tandon Air dengan Program StaadPro V8i}

Pada perencanaan konstruksi tandon, analisa struktur dilakukan dengan menggunakan program StaadPro V8i. Hasil analisa struktur untuk balok, berikut:

- Dimensi balok 25/30

- Tulangan tumpuan, tulangan atas 4D10 dan tulangan bawah 4D10

- Tulangan lapangan, tulangan atas 4D10 dan tulangan bawah 4D10

- Tulangan geser, Ø6-150

Sedangkan hasil analisa struktur untuk kolom bawah, sebagai berikut:

- Dimensi kolom 30/30

- Tulangan kolom 8D13

- Tulangan geser, Ø6-150

Dan untuk kolom atas, sebagai berikut:

- Dimensi kolom 25/25

- Tulangan kolom 8D10

- Tulangan geser, Ø6-150

Untuk struktur pelat, diperoleh hasil pelat dasar dan dinding $(15 \mathrm{~cm})$ digunakan tulangan $\varnothing 10-100$, sedangkan pada pelat atas penutup $(10 \mathrm{~cm})$ digunakan tulangan Ø10-150. Pada struktur pondasi, diperoleh kons-truksi pondasi telapak sebagai berikut:

- Ukuran pondasi 1,3 x 1,3 m

- Kolom pedestal 0,3 x 0,3 m dengan tulangan utama 8D13 dan tulangan geser Ø6-150

- Tebal pondasi $30 \mathrm{~cm}$

- Kedalaman pondasi 1,3 m

- Penulangan pondasi telapak Ø14-100

\section{Analisa Ekonomi}

Pada studi ini, analisa ekonomi dilakukan dengan 2 (dua) skenario, yaitu:
- Skenario I : operasional pompa dengan listrik

- Skenario II : operasional pompa dengan solar cell

Sedangkan penetapan harga air dilakukan berdasarkan kondisi $\mathrm{B}=\mathrm{C}$ atau $\mathrm{BCR}=1$, sehingga diperoleh harga air berdasarkan kondisi paling minimum yang dapat dikenakan pada konsumen. Tingkat suku bunga yang dipakai adalah 6,5\% dan usia guna jaringan perpipaan sampai dengan tahun 2031 .

Analisa sensitivitas dilakukan dengan berbagai tingkat suku bunga. Pada 5 (lima) tahun terakhir suku bunga BI tertinggi sebesar $7,75 \%$, sehingga analisa sensitivitas dilakukan sampai suku bunga tersebut.

Hasil analisa ekonomi proyek seperti pada Tabel 3. Biaya proyek total yang diperlukan, sebagai berikut:

a) Skenario I (operasional pompa menggunakan listrik), Rp.233.794.474,00, terdiri dari:

- Biaya modal Rp. 789.899.000,00 atau Rp. 89.468.474,00 (nilai tahunan/annual value).

- Biaya tahunan yaitu biaya opera-sional dan pemeliharaan (OP) sebesar Rp. 144.326.000,00.

b) Skenario II (operasional pompa menggunakan solar cell), Rp. 233.922.905,00, terdiri dari:

- Biaya modal Rp. 1.223.538.000,00 atau Rp. 138.584.905,00 (nilai tahunan/annual value).

- Biaya tahunan yaitu biaya opera-sional dan pemeliharaan (OP) sebesar Rp. 85.338.000,00.

Biaya modal skenario I lebih kecil daripada skenario II, dengan selisih Rp. 433.639.000,00. Namun, operasional pompa menggunakan listrik memberikan biaya operasional tahunan lebih besar jika dibandingkan dengan solar cell. Biaya OP skenario II lebih hemat Rp. 58.988.000,00 per tahunnya.

Skenario I memberikan harga air sebesar Rp. 6.700,00 per $\mathrm{m}^{3}$. Pada saat suku bunga $6,5 \%$, nilai BCR adalah 1,272. Nilai tersebut adalah layak karena BCR $>1$. Nilai Net Benefit (B-C) sebesar Rp. 63.637.607,00. Nilai B-C tersebut layak karena B-C bernilai positif. IRR sebesar 14,743\%, lebih besar dari suku bunga komersial yang berlaku dari BI (6,5\%). Titik impas investasi (payback periode) terjadi pada tahun ke 5,16 (tahun 2023). Sedangkan hasil 
analisa sensitivitas dari berbagai kondisi pada tingkat suku bunga 6,5\%-7,75\% menunjukkan bahwa nilai BCR lebih dari satu, sehingga proyek jari-ngan perpipaan ini layak untuk dibangun.

Tabel 3. Perbandingan Hasil Analisa Ekonomi Antara Skenario I dan Skenario II

\begin{tabular}{|c|c|c|c|}
\hline No. & Keterangan & Skenario I & Skenario II \\
\hline 1 & Biaya konstruksi & $\begin{array}{ll}\text { Rp. } & 702.133 .000,00\end{array}$ & Rp 1.087.590.000,00 \\
\hline \multirow[t]{2}{*}{2} & Biaya modal & $789.899 .000,00$ & $\operatorname{Rp} 1.223 .538 .000,00$ \\
\hline & Annual value & $89.468 .474,00$ & $\mathrm{Rp} \quad 138.584 .905,00$ \\
\hline 3 & Biaya tahunan & $144.326 .000,00$ & $85.338 .000,00$ \\
\hline 4 & Biaya total & 233.794.474,00 & $223.922 .905,00$ \\
\hline 5 & Harga air per $\mathrm{m}^{3}$ & $6.700,00$ & $6.550,00$ \\
\hline 6 & $\mathrm{BCR}$ & 1,272 & 1,299 \\
\hline 7 & Net Benefit (B-C) & $\begin{array}{l}\text { Rp. } \quad 63.637 .607,00 \\
\end{array}$ & Rp. $\quad 66.850 .249,00$ \\
\hline 8 & IRR & $14,743 \%$ & $12,332 \%$ \\
\hline 9 & Payback Period & 5,16 tahun & 5,96 tahun \\
\hline \multirow[t]{8}{*}{10} & $\begin{array}{l}\text { Analisa sensitivitas dengan suku bunga } \\
7,75 \%\end{array}$ & & \\
\hline & Biaya naik $10 \%$, manfaat tetap & $\mathrm{BCR}=1,116$ & $\mathrm{BCR}=1,115$ \\
\hline & Biaya turun $10 \%$, manfaat tetap & $\mathrm{BCR}=1,364$ & $\mathrm{BCR}=1,363$ \\
\hline & Biaya tetap, manfaat naik $10 \%$ & $\mathrm{BCR}=1,351$ & $\mathrm{BCR}=1,349$ \\
\hline & Biaya tetap, manfaat turun $10 \%$ & $\mathrm{BCR}=1,105$ & $\mathrm{BCR}=1,104$ \\
\hline & Biaya naik $10 \%$, manfaat turun $10 \%$ & $\mathrm{BCR}=1,005$ & $\mathrm{BCR}=1,004$ \\
\hline & Biaya turun $10 \%$, manfaat naik $10 \%$ & $\mathrm{BCR}=1,501$ & $\mathrm{BCR}=1,499$ \\
\hline & Proyek mundur 2 tahun & $\mathrm{BCR}=1,111$ & $\mathrm{BCR}=1,052$ \\
\hline
\end{tabular}

Tabel 4. Perbandingan Hasil Analisa Ekonomi Antara Skenario I dan Skenario II

\begin{tabular}{|c|c|c|c|c|}
\hline No & Keterangan & $\begin{array}{l}\text { Alternatif I } \\
\text { (Listrik) }\end{array}$ & $\begin{array}{l}\text { Alternatif II } \\
\text { (Solar cell) }\end{array}$ & Selisih \\
\hline 1 & Biaya konstruksi & Rp. 702.133.000,00 & Rp. $913.488 .000,00$ & Rp.211.355.000,00 \\
\hline 2 & OP pertahun & Rp. $144.326 .000,00$ & Rp. $85.338 .000,00$ & Rp. $58.988 .000,00$ \\
\hline 3 & Harga air per $\mathrm{m}^{3}$ & Rp. $\quad 6.700,00$ & Rp. $\quad 6.550,00$ & Rp. $\quad 150,00$ \\
\hline 4 & Nilai WTP & $4.200,00$ & $4.200,00$ & , \\
\hline 5 & Selisih harga air dan WTP & $2.500,00$ & $2.350,00$ & Rp. $\quad 150,00$ \\
\hline 6 & Total subsidi yang diperlukan & Rp. $727.133 .000,00$ & Rp. $685.400 .000,00$ & Rp. $41.733 .000,00$ \\
\hline 7 & Rincian subsidi & - Biaya konstruksi & - Solar cell & \\
\hline & & Rp.702.133.000,00 & Rp. $382.890 .000,00$ & \\
\hline & & - Biaya engineering & - Panel pompa & \\
\hline & & Rp. $25.000 .000,00$ & Rp. $\quad 8.044 .500,00$ & \\
\hline & & & - Pipa & \\
\hline & & & Rp. 294.467.849,00 & \\
\hline
\end{tabular}

Skenario II memberikan harga air sebesar Rp. 6.550,00 per $\mathrm{m}^{3}$. Pada saat suku bunga $6,5 \%$, nilai BCR adalah 1,299. Nilai tersebut adalah layak karena BCR > 1 . Nilai Net Benefit (B-C) sebesar Rp. 66.850.249,83. Nilai B-C tersebut layak karena B-C bernilai positif. IRR sebesar 12,332\%, lebih besar dari suku bunga komersial yang berlaku dari BI $(6,5 \%)$. Titik impas investasi (payback periode) terjadi pada tahun ke 6 (tahun 2023). Sedangkan hasil analisa sensitivitas dari berbagai kondisi pada tingkat suku bunga 6,5\%-7,75\% menunjukkan bahwa nilai BCR lebih dari satu, sehingga proyek jaringan perpipaan ini layak untuk dibangun.

\section{Penetapan Harga Air Berdasarkan Willingness To Pay (WTP/Kemampuan Membayar) \\ Harga air baik skenario I maupun} skenario II ditetapkan berdasarkan WTP ratarata masyarakat Desa Sumbersih yaitu $\mathrm{Rp}$. 4.200,00, oleh karena itu diperlukan subsidi dari pemerintah agar masyarakat mampu membeli air. Besar nilai subsidi dari pemerintah untuk masing-masing alternatif dapat dilihat pada Tabel 4.

Nilai subsidi yang diperlukan untuk skenario I lebih besar daripada skenario II. Selisih nilai subsidi untuk masing-masing skenario sebesar Rp. 41.733.000,00. Untuk skenario I, 
diperlukan subsidi sebesar Rp. 727.133.000,00 meliputi biaya konstruksi dan biaya engineering. Sedangkan untuk skenario II, diperlukan subsidi sebesar Rp. 685.400.000,00 meliputi biaya untuk penga-daan solar cell, panel pompa dan pengadaan pipa.

\section{KESIMPULAN}

Dari hasil perhitungan diperoleh bahwa debit kebutuhan air rata-rata Desa Sumbersih sampai dengan tahun 2031 sebesar 2,88 1/dt untuk keseluruhan daerah layanan yaitu Dusun Sumbersih dan Dusun Sumberpucung. Sedangkan besarnya keterse-diaan debit dari mata air Umbul Marijan sebesar 289,48 1/dt. Ketersediaan debit tersebut mampu memenuhi kebutuhan air bersih penduduk sampai dengan tahun 2031 dan masih terdapat sisa debit sebesar 286,60 1/dt.

Pengembangan jaringan perpipaan air bersih di Desa Sumbersih Kecamatan Panggungrejo, menggunakan 1 (satu) buah pompa Grundfos CR 15-08 dan tandon dengan kapasitas $64 \mathrm{~m}^{3}$, dengan operasi pompa selama hampir 14 jam perhari. Dari hasil simulasi Watercad V8i dapat diambil kesim-pulan bahwa kondisi hidraulis jaringan pipa masih pada batas persyaratan teknis yang ditentukan, meskipun terjadi kecepatan aliran yang terlalu lambat ketika jam rendah. Sehingga diperlukan pemasangan katub penguras.

Kualitas air Umbul Marijan telah memenuhi syarat kriteria air bersih. Untuk menjaga kualitas air tersebut, desinfeksi dilakukan pada jaringan pipa distribusi air bersih dengan menggunakan klorin cair atau Sodium Hypochlorite $(\mathrm{NaOCl})$. Mekanisme penginjeksiannya dilakukan pada pipa inlet tandon sebesar 0,4 $\mathrm{mg} / \mathrm{l}$ secara konstan.

Dari hasil analisa ekonomi diperoleh harga air sebesar $6.700,00 / \mathrm{m}^{3}$ (skenario I) dan $6.550,00 / \mathrm{m}^{3}$ (skenario II), sedangkan nilai Willingness To Pay (WTP) rata-rata sebesar Rp. 4.200,00, sehingga diperlukan subsidi dari pemerintah agar masyarakat mampu membeli air. Berdasarkan hasil tersebut maka dapat disimpulkan bahwa skenario II lebih menguntungkan karena membutuhkan subsidi pemerintah lebih kecil.

\section{DAFTAR PUSTAKA}

Kementerian Pekerjaan Umum dan Perumahan Rakyat. 2016. Peraturan Menteri Pekerjaan Umum dan Perumahan Rakyat No: 27/ PRT/M/2016 Tentang Penyelenggaraan Sistem Penyedian Air Minum. Jakarta.

Dinas PU Cipta Karya dan Tata Ruang Prop. Jawa Timur. 2014. Laporan Akhir Perencanaan Tindak Lanjut Penanganan Kekeringan Daerah Rawan Air Kab. Blitar Tahun 2014.

Giatman. 2007. Ekonomi Teknik. Jakarta: PT. Raja Grafindo Persada.

Kodoatie, Robert J. 2005. Analisis Ekonomi Teknik.Yogyakarta: Penerbit Andi Yogyakarta.

Kuiper, E. 1971. Water Resources Projects Economics. Butterworths, London, England.

Listiyaningrum, et.al. 2015. Analisa Simulasi Perubahan Konsentrasi Klorin Da-lam Pipa Distribusi Penyediaan Air Minum PDAM Demak Zona 3. Jurnal Teknik Lingkungan, Volume 4, No. 2 (2015).

Lufira, R.D. 2012. Optimasi Dan Simulasi Sistem Penyediaan Jaringan Air Bersih Di Kecamatan Kademangan Kabupaten Blitar. Tesis. Tidak dipublikasikan. Malang: Universitas Brawijaya.

Muliakusumah. 1981. Proyeksi Penduduk. Jakarta: Lembaga Penerbit Fakultas Ekonomi Universitas Indonesia.

Rossman, L. A. 2000. EPANET Version 2 User Manual. United States Environmental Protection Agency, Cincinnati.

Suprihatin, et.al. 2013. Teknologi Proses Pengolahan Air. Bogor: PT Penerbit IPB Press.

Triatmadja, R., et.al. 2006. Simulasi Hidrolika dan Kualitas Air dalam Jaringan Air bersih. Prosiding Seminar Nasional Implikasi Peman-faatan Potensi Dan Tata Ruang Terhadap Pengelolaan Sumber Daya Air: Bandung: Jurusan Teknik Sipil Institut Teknologi Nasional.

Triatmadja, R., 2016. Teknik Penyediaan Air Minum Perpipaan. Cetakan pertama. Yogyakarta: Gadjah Mada University Press. 